Article

\title{
Steering as Path Creation: Leadership and the Art of Managing Dependencies and Reality Effects
}

\author{
Kristof Van Assche ${ }^{1}$, Martijn Duineveld ${ }^{2, *}$, Monica Gruezmacher ${ }^{1}$ and Raoul Beunen ${ }^{3}$ \\ ${ }^{1}$ Department of Earth and Atmospheric Sciences, University of Alberta, Canada; E-Mails: vanassch@ualberta.ca (K.V.A.), \\ gruezmac@ualberta.ca (M.G.) \\ ${ }^{2}$ Department of Environmental Sciences, Wageningen University, The Netherlands; E-Mail: martijn.duineveld@wur.nl \\ ${ }^{3}$ Faculty of Science, Open University, The Netherlands; E-Mail: raoul.beunen@ou.nl \\ * Corresponding author
}

Submitted: 18 January 2021 | Accepted: 8 April 2021 | Published: 25 June 2021

\begin{abstract}
We develop a perspective on steering in governance which understands steering as intended path creation. Inspired by evolutionary governance theory, critical management studies and social systems theory, we argue that steering is shaped and limited by co-evolutions, disallowing for any formulaic approach. In order to illuminate the space for steering in governance, we analyze the interplay between different dependencies. Those dependencies are not just obstacles to path creation, they can also be pointers and assets. The steering discussion is further complicated by always unique sets of couplings between a governance system and its environment. After introducing the ideas of reality effects and governance strategy, we further develop our concept of steering and present it as the management of dependencies (in governance) and reality effects (outside governance) towards path creation. This management is ideally strategic in nature and requires leadership in a new role.
\end{abstract}

\section{Keywords}

dependencies; governance; leadership; path creation; reality effect; steering

\section{Issue}

This article is part of the issue "Steering in Governance: Evolutionary Perspectives" edited by Kristof Van Assche (University of Alberta, Canada / University of Bonn, Germany) and Raoul Beunen (Open University, The Netherlands).

(C) 2021 by the authors; licensee Cogitatio (Lisbon, Portugal). This article is licensed under a Creative Commons Attribution 4.0 International License (CC BY).

\section{Introduction}

Societal steering through governance is a highly debated topic. Questions regarding what can be changed in society by means of planning, policies and law have been discussed for centuries and have received many divergent answers. Divergence in ideas has been tied to different disciplinary traditions, schools of thought and ideologies (Hillier, 2002; Scott, 1998; Willke, 2014). Whereas severe critiques of steering have developed since the 1960 s in a variety of disciplines, very strong steering ambitions re-emerged with the rising popularity of transition thinking (Kemp et al., 2007; Rotmans \& Loorbach, 2009), innovation thinking (Beckert, 2016; Bledow et al.,
2009), social-ecological systems perspectives (McLain \& Lee, 1996) and climate change adaptation theories (Paschen \& Ison, 2014; Rip, 2006). In parallel, one can observe the survival of modernism in policy, planning and administration, where the promise of social engineering remains alluring (Czarniawska, 2002; Gunder \& Hillier, 2009; Lindberg et al., 2015; Luhmann, 1990; Seidl, 2007).

Rather than re-summarizing the defenders and critics of modernism, we present a perspective on steering which gives due weight to processes of co-evolution. Taking cues from evolutionary governance theory (EGT) we intend to explore the middle ground between naïve steering optimism and cynicism (Van Assche et al., 2013). 
EGT retains the possibility that action is strategically oriented while questioning modernist assumptions. By modernist assumptions we refer to ideas of objectivity, universality, longevity of the knowledge underpinning steering, perfect knowledge integration and the susceptibility of realities to steering attempts (Van Assche, Beunen, \& Duineveld, 2014; Van Assche et al., 2020a). Steering remains possible but will encounter unique enabling factors and obstacles in each governance system and each project.

Governance powers are always unique, as governance paths are unique. Intention and strategy are constrained by different sets of dependencies (Beunen et al., 2015; Tadajewski et al., 2011). Those dependencies affect how actors and institutions are formed, how they interact and how the governance configuration transforms itself over time. EGT distinguishes between path dependencies, interdependencies, goal dependencies and material dependencies. Path dependencies, theorized and recognized in several disciplines (David, 2007; Pierson, 2000), are legacies from the past affecting the functioning of the governance configuration. Interdependencies are current relations between elements of governance which shape and constrain the transformation of the system while goal dependencies are the effects of envisioned futures on the governance system. Goal dependencies can take forms wildly different from 'implementation' (cf. Pressman \& Wildavsky, 1984) and can stem from futures embraced or feared by actors in governance, from futures visibly or implicitly encoded in institutions (policies, plans, laws) (Hoch, 2016) and from interactions between those futures and the other elements in the configuration. Finally, the theory recognizes material dependencies, the effects of natural and human made physical environments and infrastructures on governance (Duineveld et al., 2017; Van Assche et al., 2020a).

Path creation refers to the agency through which actors create and exercise alternative options in a governance path (Garud \& Karnøe, 2001a, 2001b; Garud et al., 2010). We develop the concept of path creation within an EGT perspective and argue that steering has to be understood as a process of deliberate yet not necessarily strategic path creation. This claim will be unpacked in the rest of the paper. The distinctive character of the EGT version of steering will gradually become more pronounced as will the distinction with modernist understandings of steering.

Within an evolutionary understanding of governance, strategies in governance are strategies addressing communities bound by the decisions taken in the governance system (Van Assche et al., 2020b). They connect a vision of a desirable long-term future with policy tools and function as an institution themselves. In other words, they have a narrative and institutional dimension. The strategizing envisioned here is the strategy by and for a collective. In our analysis of path creation and steering we will need to consider what this means for notions of leader- ship, as leaders have been traditionally associated with both path creation and strategy (Czarniawska-Joerges \& Wolff, 1991; Garud \& Karnøe, 2001a; Young, 1991).

In the next section we first specify the theoretical perspective of EGT and its implications for a new understanding of path creation. We then analyze what steering, as intended path creation, could look like in terms of the types of change which can be produced according to EGT. Here we introduce the concept of reality effects, changes in the experienced reality of the community to be steered. This leads into a discussion of the system relations which have to be invoked to explain the possibilities and limits of steering. For communities as well as for organizations and their leaders, we draw out the implication that steering is an art, requiring considerable skill in managing dependencies and managing the reality effects of policy and planning.

\section{Path Creation}

Both path dependence and path creation have received considerable attention in several disciplines (Bakken et al., 2010; Flyvbjerg et al., 2003; Lovio et al., 2011; Schienstock, 2004; Stack \& Gartland, 2003). Focusing here on path creation, we can say that the most influential theorists on path creation can be found in the modernist camp and prefer to take a rather formulaic approach (Garud \& Karnøe, 2001a, 2001b; Garud et al., 2010). Usually there is a belief in the objective possibility of path creation, and in its predictability and susceptibility to engineering. Conditions of the governance system might be specified as an enabling context for path creation (if $X$ and $Y$ are the case in governance, then path creation will ensue).

Co-evolving elements in governance, however, make it hard to anticipate or engineer path creation. The idea of co-evolution in governance introduces unpredictability, knock-on effects and the notion that the emerging path is contingent on the actions and decisions made by many. Those actions can include strategizing against intended path creation. In governance, actors co-evolve with institutions, with each other, with narratives and forms of knowledge. In addition, formal and informal institutions shape each other over time and material infrastructures can have institutional and cognitive effects which are not entirely observable from within the governance system (Beunen et al., 2013; Jacobsson et al., 2015; Kjaer \& Vetterlein, 2018; Van Assche et al., 2013). The presence of path creation might therefore not be easily agreed upon by internal observers. Moreover, governance can create actors, institutions, forms of knowledge and materialities that can affect what is possible in terms of steering later on (Duineveld et al., 2017; Frederiksen, 2016; Van Assche et al., 2020a). The goal dependencies can entail entirely unanticipated reactions to steering attempts (Tadajewski et al., 2011; Teubner, 1998). These reactions can then trigger path creation which might not be expected nor observed (as it was not 
expected in the first place). Taking into account these limitations, path creation is nevertheless possible as a result of contingent events and because of the agency and leadership of actors (Alvesson et al., 2016; Van Assche et al., 2013; Van Assche, Beunen, \& Duineveld, 2014; see Figure 1).

The interplay between different dependencies creates rigidities but also flexibility. This flexibility is possibly a counter-intuitive feature of governance evolution. On second inspection, it is not so strange as path dependencies and interdependencies can also be leverage points and assets for change (cf. Schienstock, 2004). Whether or not they become obstacles for change depends on context, perspective and goal (Harrison et al., 2019; Hautz et al., 2017). Novelty can arise and path creation can occur through the interplay of dependencies (Schirmer \& Hadamek, 2007). A different way of understanding this is to emphasize the modification of dependencies by each other. A material dependency can reinforce or weaken a path dependency; a goal dependency is modified by material dependencies and the result of those modifications can be, in some cases, path creation (Duineveld et al., 2017; Van Assche et al., 2021). Managing this complexity is never perfect and can be viewed as managing dependencies as opposed to eliminating them. Ultimately, managing the other dependencies is needed to make goal dependencies more predictable and manageable. In order to maximize the effects of a governance strategy in the community, its internal effects within governance have to be grasped first.

Steering as intended path creation can take many forms and follow many routes. Considering the variety in governance paths empirically observed by anthropologists (Gledhill, 2009), by EGT and others, a diversity of steering mechanisms and pathways seems natural (cf. Flyvbjerg, 1998). Path creation can be a fast or a slow process. It can involve a long-term vision, an ad hoc adaptation or shorter-term goals, and it can focus on changes in governance or in society at large.

Thus, steering does not necessarily involve strategy (cf. Garud et al., 2010; Teubner \& Willke, 1984). Intention is present in all the forms of steering listed above, even where steering is triggered by tactics rather than strategy, even if it is the result of an adaptation that is felt as neces- sary. In any case, goals still need to be set, time horizons need to be defined and action needs to be coordinated. There are however clear benefits to adopting a form of strategy: a greater degree of coordination and the promise of managing effects in the longer run (cf. Bledow et al., 2009; Clegg et al., 2004). The diversity of forms of path creation predicted by EGT and observed empirically by many (Alvesson, 1993; Alvesson \& Spicer, 2016; Beckert, 2016; Mintzberg \& Waters, 1985; Van Assche et al., 2020b, 2021) marks a clear difference with modernist ideas of steering.

\section{Goals and Reality Effects}

For EGT, goals engender dependencies. Therefore, steering attempts also have this effect. As we know, goal dependencies are effects of goals within the governance system. Because governance binds a community to its own decisions, internal effects of those decisions can also have external effects. Goal dependencies can translate into external effects that are not necessarily in line with the intentions behind a steering attempt. When external effects are in line with the steering intention, this can reinforce the belief in 'implementation' (Barrett, 2004; MacKenzie et al., 2007). More often, effects are not obviously aligned with intentions. The effects of goals within governance can vary widely because of the diversity of interactions in the governance network: between actors, between institutions (both formal and informal), between power and knowledge, and between knowledge and actors. All these interactions influence the relation between goals and their effects.

Goals thus trigger goal dependencies depending on the structure of the governance configuration and the behaviour of the actors. The translation of goal dependencies into external effects will hinge on the same factors. Beyond a similarity or conformity with the goals set, there can be affinity in spirit (Barrett, 2004; Faludi, 1973), the resistance touched upon and a variety of other effects (Brans \& Rossbach, 1997; Luhmann, 1989, 1990).

Of particular interest for our present discussion are those effects that set in motion the creation of new realities, what we call reality effects (cf. Van Assche et al., 2020a; Žižek, 1989). We distinguish between two types

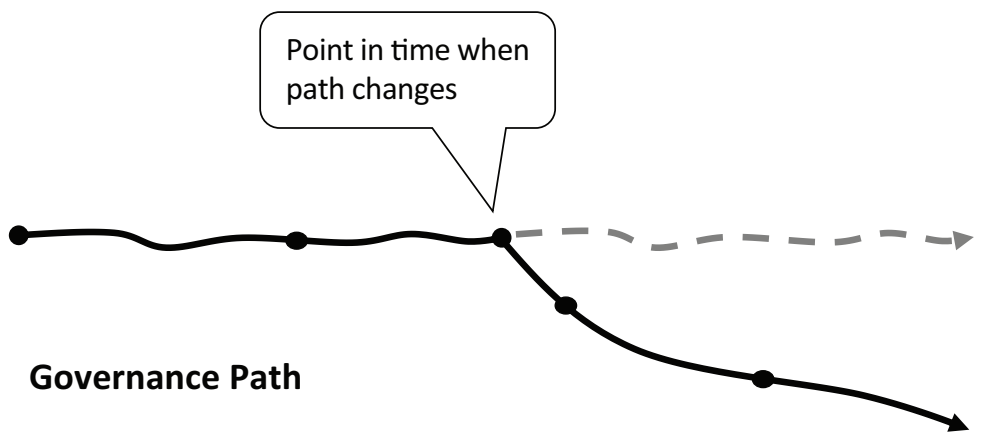

Figure 1. Path creation in governance. Path creation can be intended or not intended, it can be strategic in nature or nonstrategic. The point where the path changes and dependencies are reshuffled is sometimes recognized only in hindsight. 
of reality effects: discursive and material. Discursive and material changes affect each other. An infrastructure project can embody a new future and convince citizens that this future is real (Flyvbjerg et al., 2003; Scott, 1998). Conversely, a new belief in social engineering, pervading society and governance, can generate new infrastructures (Figure 2).

If reality effects are in line with the initial intention of those steering, we can speak of performativity (Beunen et al., 2013). This does not always mean however, that the world has become as was intended by the policy or plan or that the world has been changed at all. This is possible but whether performativity can indeed be ascribed to implementation has to be diagnosed for each situation (cf. Willke, 2014). Often, the result of steering attempts is convincing for other reasons. Actors in governance might believe in steering success and convince others. Or they might perform success by reinterpreting the current situation as positive and as resulting from policy intentions (Seidl \& Becker, 2005; also cf. Luhmann, 1995, 1997). Both citizens and actors in governance might believe the story anyway, so no performance of success is even needed. Experts can play a role by providing measurements of policy outcomes, through accounting systems, indicators and assessments (Carter et al., 2010). These measurements and tools can be used to render narratives more true (Turnhout et al., 2007; Verschraegen, 2015).

Another path to performativity appears when discursive or material realities have shifted, even without performance of success. Consider severe flooding events that portray climate change more clearly; imperceptible shifts in the notion of democracy (changes in discursive reality) might erode the belief in the current leadership and governance systems. Leadership and steering systems are reinforced when contingent events make it look like the world is as intended by those steering. Interpretation is always involved, as direct causality between steering and effects can almost never be established (Paterson \& Teubner, 1998; Seidl, 2016). Both organizations (in governance) and the function system of politics (governance being politics in the broad sense) rely on a posteriori ascription of intention, causality and success of steering (Alvesson et al., 2016; Luhmann, 1990, 2018; Mintzberg \& Waters, 1985).

Performativity is an effect of discourse. Discursive configurations and discourse coalitions, entrenched narratives and ideologies and deeply rooted metaphors can make performativity more likely (Beunen et al., 2013; Hillier, 2002; Rap, 2006). However, classic steering theory and modernist policy theories are not always wrong and straightforward implementation is possible under certain conditions. Some of those cases can entail path creation, can be considered steering. Performativity does not always have to be invoked. One can think of situations marked by limited steering ambitions, smaller projects, shorter term goals. Even more complex schemes for the long term can work through the logic of implementation, as when people are dependent on the strategizing authorities or coerced by them (Alvesson \& Spicer, 2016; Ferguson, 1990) or when discourse on is widely shared and steering power is widely accepted. Such sharing and acceptance together generate legitimacy, which offers further support for implementation (Van Tatenhove, 2011). What differs in our perspective is quite simply that one cannot assume as a rule that central steering and implementation will work. Positing the existence of a general rule in a situation marked by complexity, co-evolution and contingency simply makes the situation harder to manage (Alvesson, 1993; Alvesson et al., 2016).

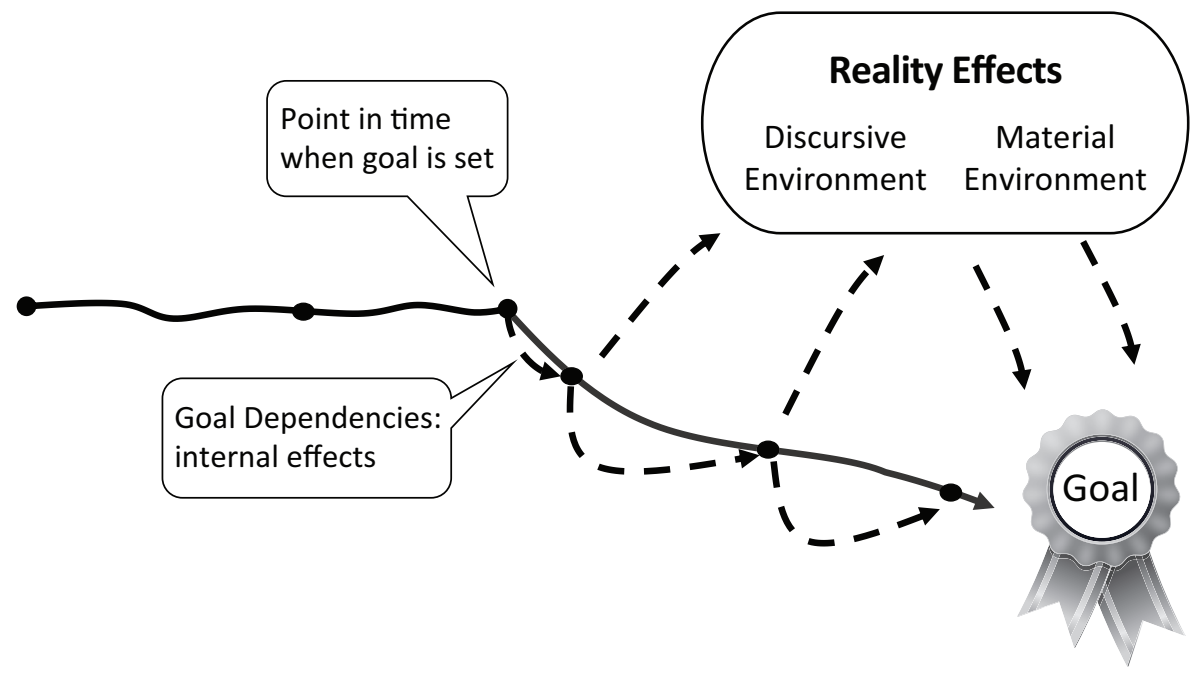

Figure 2. Steering as intended path creation. Goal dependencies and reality effects align. The set goal triggers goal dependencies in governance and those dependencies are predictable enough to maintain the course. The effects of governance on discursive and material environments (reality effects) align as well. The result is performativity of the most desirable sort, i.e., coming about through intended path creation, through steering. 


\section{Systems Relations and Reality Effects}

Material dependencies are effects of the physical world on governance (Van Assche et al., 2020a). Material dependencies, just as the goal dependencies discussed above, can lead to reality effects-but not necessarily. A wetland might resist any attempt at land reclamation, independent of any effect the struggle against flooding might have had on the discourses pervading land policy (cf. Valentinov, 2017). Other things might be happening in the place supposedly steered. Other policies might have led to interventions in the local landscape. Ongoing landscape changes, whether induced by policy or not, might entwine with the intervention envisioned in steering (Lovio et al., 2011). Finally, it can happen that ambitious steering schemes produce sub-goals which can contradict each other, reinforce each other or otherwise interact in their material effects, more generally in their reality effects (Hyysalo et al., 2019; Jacobsson et al., 2015).

Reality effects will likely be greater when governance system and community share goals and values, perhaps grounded in narratives on what the good life or good community is. Reality effects will also be reinforced if beliefs about governance itself are shared. That is, if people believe in particular procedures and routines, in particular forms of hierarchy and authority, it is easier to exercise that authority. Luhmann (1997) already revealed the best recipe for successful planning: people who are accustomed to planning. In a similar vein, Alvesson and Spicer (2016) mention how organizations' religious belief in leadership leads them to seek for solutions to all their problems by strengthening leadership. Shared discourse can contribute to local understandings of steering interventions as logical, natural and legitimate (Bakken et al., 2010; Bartel \& Garud, 2009; Hüther \& Krücken, 2013). Technocracy, with expert groups taking a central place in governance, can function more easily in either very authoritarian societies or places with great respect for expertise (Ferguson, 1990; Scott, 1998).

Each governance path embodies a particular set of relations with the surrounding systems. It embodies a governance path shaped by a unique set of environments (Valentinov, 2014). Each path, in its unique set of environments, can enable particular forms of steering, can make them imaginable, possible to articulate and translate in terms of actors and institutions, power and knowledge (Schirmer \& Hadamek, 2007; Seidl, 2016; Willke, 2014). The dependencies shaping governance will also shape the effects of governance action in the environment as they modify the translation of decisions into other more specified decisions and into action outside governance. Referring to the dependencies is not enough though, as the nature of the couplings with the surrounding environments enables certain decisions to have more impact than others. Dependencies shape and are shaped by the couplings with the environments they exist in.

A steering attempt crystallizing in a particular path will receive responses from its unique set of coupled and co-evolved environments. It can be associated with a unique matrix of possible interventions and a matrix of possible reactions to those interventions. In other words, the reality effects of steering attempts will be modified by the features of both system and environment (cf. Luhmann, 1989). Reality effects result from a slowly individualized history of a system in an environment. Sometimes the constraints to steering, the limits to intervention and to performative reality effects can be located, first of all, in the possibilities within the system to observe, imagine and coordinate. In other cases, the constraints are more a matter of environments remaining opaque or systems relations disallowing a particular form of coordination (Lindberg et al., 2015; Mintzberg \& Lampel, 1999).

\subsection{Systems Relations and Leadership}

Leadership in such context thus requires knowledge of both the governance system and the relevant environments (Rotmans \& Loorbach, 2009; Van Assche et al., 2020a). Understanding the couplings between governance and its environments is understanding informal institutions, as these are often the basis for, or alternative to, the formal institutions developed in governance (Helmke \& Levitsky, 2004). Leaders therefore cannot identify uniquely with the governance system and cannot derive their knowledge entirely from within the system. They need insight in the interplay between formal and informal institutions (Van Assche, Beunen, \& Duineveld, 2014), an insight which more easily develops when one can shift easily between insider and outsider perspectives.

The choice to pursue discursive versus material reality effects, in articulating strategy, and the crafting of the performance towards performativity, requires leadership. Neither a checklist nor a recipe will deliver the strategy (Golsorkhi et al., 2010; Whittington, 1996). Judgment is required, inspired by knowledge of system and environment (Flyvbjerg, 1998, 2001; Flyvbjerg et al., 2003; Voß \& Freeman, 2016). Positive or negative reinterpretations of previous steering attempts are part and parcel of this kind of leadership (Czarniawska-Joerges \& Wolff, 1991). Convincing people that previous interventions were a success (or not) sets the tone for the next cycle of problem definition, choice of tools and goals. It frames the narratives that are more likely to be persuasive (Beunen et al., 2013; Rap, 2006).

\subsection{Steering as Self-Steering}

Steering in this perspective emerges as self-steering (cf. Ahrne \& Brunsson, 2008; Brans \& Rossbach, 1997; Teubner \& Willke, 1984; Willke, 2014). Without understanding the mechanisms of governance, without grasping the potential to anticipate and to strategize for a given governance system, it is hard to be successful in steering outside governance (cf. Alvesson, 1993; Kjaer \& 
Vetterlein, 2018; Seidl, 2007; Van Assche et al., 2020b). We encounter again the double nature of strategy: strategizing actors in governance and actors coordinating in the articulation of collectively binding strategies. Reality effects of steering come about through strategic use, first of the resources of the governance configuration itself and next the resources of the community the steering is destined for.

Sometimes new governance modes are necessary in order to pursue a particular steering ambition. Whether internal reshuffling or governance reform has to precede steering is a matter pertaining to individual cases and strategies (Van Assche et al., 2017, 2020a). The same goal might be reached with or without governance reform while reformed governance might still reproduce rigidities standing in the way of path creation. One can then again distinguish between an EGT perspective on steering and modernist understandings. An EGT perspective can be more sensitive to the multiplicity of environments affected by and affecting steering. This understanding of steering is also more alive to the importance of history: unique co-evolutions create unique possibilities for steering. Due weight is given to the detours through the internal environment of governance, needed to achieve external effects (Willke, 2007).

\section{Art of Steering}

All the above brings us to the idea that steering is more art than science. It is an art in the sense that design is an art-we could add management to the list (Colander \& Kupers, 2016). Both steering and management require judgment more than skill or science (Flyvbjerg, 1998; Hautz et al., 2017). Steering, design and management require insight in a specific system, in specific systemenvironment relations, which can then help the practitioner to anticipate the system state after intervention and the possible interventions leading to a particular system state (cf. Newig et al., 2013; Van Assche et al., 2019).

\subsection{Art of Steering and Complexity}

Science can produce recipes for partial and simple problems of design, management and steering but not for those which combine competing knowledges, values, perspectives and entanglements of past, present and future (Flyvbjerg, 2001; Schirmer \& Hadamek, 2007; Seidl, 2016). Steering of complex systems, in this case complex governance systems aiming to reshape their communities, is not a matter of further developing techniques that worked on partial problems. This is the case because complex problems cannot always be reduced to a set of simple problems - the classic issue of reductionism. Complex problems, as complex systems, are characterized by processes of emergence (Von Bertalanffy, 2015). A problem can slowly emerge as something qualitatively different from its constituent parts (Seidl, 2007; Van Assche et al., 2019). A new logic of problem repro- duction might emerge which is not grasped by decisionmakers (Dunleavy \& Hood, 1994; Hood \& Peters, 2004). Which implies that the timing of intervention makes all the difference-an insight eluding modernist versions of the steering concept.

Luhmann (2018) and the organization theorists inspired by him (collected in Seidl \& Becker, 2005) would add that management, design and steering are about decisions and that decisions cannot be reduced to the reasoning or the knowledge used to come to them. A decision cannot be deduced. Adding more knowledge or rendering the decision formulae more complex does not eliminate this gap. The gap remains and the jump remains necessary. Any decision is underdetermined by the preceding knowledges: No knowledge necessarily leads to a particular decision. This is true for organizations (Alvesson, 1993; Bakken et al., 2010; Bledow et al., 2009) and it is true for steering through governance. Moreover, in governance, the embedded combination of knowledges is under continuous political pressure (Hillier, 2002). This is understandable, as political preferences change and as the situation changes (Flyvbjerg, 1998; Fournier \& Grey, 2000; Lindberg et al., 2015; Scott, 1998). The usual instability of knowledges in governance further limits the possibilities for formulaic versions of strategy and steering (Grabher, 2004).

More hurdles for steering can be found in limitations on transparency in complex governance systems. These limitations stem from the nature of governance as an intricate web of actors, many of which are organizations, not entirely transparent to each other. Strategizing in governance is often invisible, as is part of the resistance within the community. Informal institutions might not be acknowledged or understood (Helmke \& Levitsky, 2004; McFarlane, 2012). On the other hand, governance configurations exert power, beyond that of any actor. So, with myriad limitations to steering and a great distance from scientific problem-solving or engineering, comes a world of new possibilities, if steering is exercised as an art. That art of steering requires a deep familiarity with the tools of governance, its possibilities of storytelling, its internal strategies, its modes of persuading and regulating the collective (Ahrne \& Brunsson, 2008; Czarniawska, 2002; Kjaer \& Vetterlein, 2018; Throgmorton, 2003; Van Assche et al., 2020b).

\subsection{Leadership and Temporality}

Leadership, both in organizations and in community governance, is constrained in ways not fully recognized by most management literature. Alvesson and Spicer (2016) masterfully analyzed many of these unrecognized constraints and prevalent mythologies. Our perspective does reveal new roles and new tools for leadership. We argued that what needs to be managed are dependencies and reality effects. Managing reality effects naturally entails managing dependencies, as knowledge of the dependencies is knowledge of the fine mechanics of governance. 
Jumping between system and environment in the continuous assessment of steering options has to be an art, per definition imperfect. Steering demands a creative shifting between system and environment and between what is and what could be (Van Dijk, 2011). Rules, routines and decision-support systems cannot replace judgment (phronesis, to borrow a term from Flyvbjerg, 1998). Steering in governance is more than deciding between alternative futures. It can be more aptly likened to constructing a new future based on opaque preferences in imperfectly understood environments.

The same EGT-inspired perspective which thus emphasized steering problems can still accommodate a variety of steering tools for leadership. A vast repertoire of stratagems can be useful in the management of reality effects and dependencies. Without any ambition to present an exhaustive list we can mention: modifying materiality, inventing discourse, altering system relations, sharing semantics, sharing goals between systems, using bridging organizations, crystallizing new modes of observation, building meta-knowledges and narratives, inventing "sticks and carrots" schemes, creating new organizations and/or institutional work, creating conflict or consensus, modifying patterns of inclusion and exclusion in governance, creating new actors, de-coupling and re-coupling systems, using episodes of decision making and delineating sites for conflict or increased ambition (Beunen \& Patterson, 2019; Brans \& Rossbach, 1997; Grabher, 2004; Hyysalo et al., 2019; Newig et al., 2013; Rotmans \& Loorbach, 2009; Seidl, 2007; Van Assche \& Verschraegen, 2008).

In the use of those tools, timing is of the essence. Windows of opportunity have to be grasped, in governance, its environments and in the pattern of couplings. Knowledgeable and creative leadership is more likely to observe such windows. Creativity enters the story again since a window is only a window if something is seen. In the choice of tools also timing and deep familiarity with system and environment are important. The hands of time mould policy instruments as well as their effects (Van Dijk, 2006). Tools can work in a particular environment yet lose their coordinative power when values, ideologies, actors change or when a perceived failure taints the tool and its users (e.g., Innes, 1989).

Our analysis seems to produce a dilemma in this regard. On the one hand stable leadership is beneficial because it takes time to learn about the governance system, its modes of self-transformation, its informalities and power relations and to learn about system-environment relations and the history of previous steering attempts. On the other hand, the time it takes to develop such knowledge may conflict with the pace of change which increased because of technological and environmental shocks (Folke, 2006). The various sources of radical uncertainty and opacity diagnosed aggravate the situation because they seem to undermine the value of knowledge and timing and seem to increase the value of rapid adaptation and likely of new leadership-a fresh perspective.
This dilemma is real, we would argue, and we would add that it is a dilemma that will always be there. Familiarity can breed identification, routine solutions, rigidity and blind spots. A long tenure can dissipate creativity and erode authority by creating a web of dependency relations around the leader (Orpen, 1996). Time also gives opportunity for opponents to elaborate their own strategies and for opponents to form (Van Assche et al., 2020b, 2021). At a given moment, the skill set and personality of a leader can fit the circumstances. As those circumstances are never fully grasped, unobserved changes might render that leader less effective over time (Jay, 1967). The dilemma is a version of the insider/outsider dynamic often remarked upon. Insiders and outsiders are always observing different things and both positions come with pros and cons in terms of understanding and organizing (Louis \& Bartunek, 1992; Wagner et al., 1998).

In practical terms, this state of affairs does not render leaders redundant, nor does it make steering impossible. The benefits of knowledge and stability are there, as are the risks. This does not amount to a general argument for avoiding knowing, for speed in decisionmaking or for unstable leadership (Alvesson et al., 2016). In governance, leadership can be distributed, institutional memory can be helpful and trusted advisors can play a key role in the learning process of new leaders. One could even say that the dilemma is something that can be managed collectively in democratic forms of governance, where stakeholders outside governance can signal change or disaffection and can trigger a change in leadership. The dilemma, its non-reducibility, underlines that managing path creation is an art, with no artist capable of pleasing all patrons. Still, it is an art requiring and recognizing skill and experience.

\section{Conclusion}

We presented a perspective on steering in governance which understands steering as deliberate path creation. Taking a distance from modernist ideas of path creation and of steering in policy, administration and planning, we rely instead on insights from EGT, critical management studies and social systems theory to place path creation in the context of evolving governance configurations. Each governance path is marked by dependencies and rigidities. Path creation is not merely the overcoming of such rigidities but the thoughtful use of them. Dependencies might be constraints, but they are also just features, aspects of the identity of the configuration. This means that they need to be taken into account. They can guide steering and can become major assets, an insight presaged by Goethe's saying that mastery is managing limitations.

The outside, the world of community and society, of other function systems and organizations is always shaping and being shaped by governance. Managing couplings, knowing both the inside and the outside is 
therefore of the essence if steering is the intention. For deliberate path creation, leadership needs to be steeped in the stories and forms of coordination prevailing in governance and the environment that is supposed to be coordinated by it. While our analysis highlights the benefits of experience and knowledge on the part of leadership, it also acknowledges that complete identification with a particular governance tradition is a risk, a rigidity and limitation.

Leadership for path creation is risky as path creation involves risk. Any substantial change in governance and its effects is likely to provoke resistance inside and outside the sphere of governance. Dealing with such resistance requires great sensitivity for what is felt in the governance system and the community. Management of reality effect requires the same kind of observational skills and wide range of communicative, interpretive, negotiation and coalition building skills that is required for managing dependencies and which can be summed up as strategy skills. The impossibility of scientific management does not preclude management.

Steering as path creation is thus management of dependencies in governance and reality effects of governance. Steering is more than techne, it is art. It requires phronesis more than calculation or deliberation and it is conducted by leadership in governance systems that are themselves continuously transformed by their previous operations. Steering can be path creation for the shortterm and it can also be quickly decided. Circumstances might demand such course of action. Yet, ambitious steering attempts, those emerging as response to major challenges the world is facing, do require strategy. That is, they demand the construction of a long-term future and its translation into coherently connected institutions. Strategic action by individual actors can hinder or enable such collective strategy.

The world that emerges from our analysis is one where steering is possible, where leadership is needed and where outsiders can sometimes become leaders and take big and fast decisions reshaping a community. Sometimes, slow deliberation and careful scientific planning will deliver strategies that are implementable and put a community on a different course. In most cases however, neither of those options will work out well and leadership of the sort argued for here, aware of context, of its own limitations and of the contingencies of strategy in governance, will be better suited.

\section{Acknowledgments}

We would like to thank the anonymous reviewers for their insightful comments and suggestions.

\section{Conflict of Interests}

The authors declare no conflict of interests.

\section{References}

Ahrne, G., \& Brunsson, N. (2008). Meta-organizations. Edward Elgar Publishing.

Alvesson, M. (1993). Organizations as rhetoric: Knowledge-intensive firms and the struggle with ambiguity. Journal of Management Studies, 30(6), 997-1015.

Alvesson, M., \& Spicer, A. (2016). The stupidity paradox: The power and pitfalls of functional stupidity at work. Profile Books.

Alvesson, M., Blom, M., \& Sveningsson, S. (2016). Reflexive leadership: Organising in an imperfect world. Sage.

Bakken, T., Hernes, T., \& Wiik, E. (2010). Innovation and organization: An overview from the perspective of Luhmann's autopoiesis. Emerald Group Publishing.

Barrett, S. M. (2004). Implementation studies: Time for a revival? Personal reflections on 20 years of implementation studies. Public Administration, 82(2), 249-262.

Bartel, C. A., \& Garud, R. (2009). The role of narratives in sustaining organizational innovation. Organization science, 20(1), 107-117.

Beckert, J. (2016). Imagined futures: Fictional expectations and capitalist dynamics. Harvard University Press.

Beunen, R., \& Patterson, J. J. (2019). Analysing institutional change in environmental governance: Exploring the concept of 'institutional work.' Journal of Environmental Planning and Management, 62(1), 12-29.

Beunen, R., Van Assche, K., \& Duineveld, M. (2013). Performing failure in conservation policy: The implementation of European Union directives in the Netherlands. Land Use Policy, 31, 280-288.

Beunen, R., Van Assche, K., \& Duineveld, M. (2015). Evolutionary governance theory. Springer.

Bledow, R., Frese, M., Anderson, N., Erez, M., \& Farr, J. (2009). A dialectic perspective on innovation: Conflicting demands, multiple pathways, and ambidexterity. Industrial and Organizational Psychology, 2(3), 305-337.

Brans, M., \& Rossbach, S. (1997). The autopoiesis of administrative systems: Niklas Luhmann on public administration and public policy. Public Administration, 75(3), 417-439.

Carter, C., Clegg, S., \& Kornberger, M. (2010). Re-framing strategy: Power, politics and accounting. Accounting, Auditing and Accountability Journal, 23(5), 573-594.

Clegg, S., Carter, C., \& Kornberger, M. (2004). Get up, I feel like being a strategy machine. European Management Review, 1(1), 21-28.

Colander, D., \& Kupers, R. (2016). Complexity and the art of public policy: Solving society's problems from the bottom up. Princeton University Press.

Czarniawska, B. (2002). A tale of three cities: Or the glocalization of city management. Oxford University Press.

Czarniawska-Joerges, B., \& Wolff, R. (1991). Leaders, managers, entrepreneurs on and off the organiza- 
tional stage. Organization Studies, 12(4), 529-546.

David, A. P. (2007). Path dependence: A foundational concept for historical social science. Cliometrica, 1, 91-114.

Duineveld, M., Van Assche, K., \& Beunen, R. (2017). Reconceptualising political landscapes after the material turn: A typology of material events. Landscape Research, 42(4), 375-384.

Dunleavy, P., \& Hood, C. (1994). From old public administration to new public management. Public Money \& Management, 14(3), 9-16.

Faludi, A. (1973). Planning theory: Urban and regional planning series. Pergamon Press.

Ferguson, J. (1990). The anti-politics machine: 'Development,' depoliticization and bureaucratic power in Lesotho. Cambridge University Press.

Flyvbjerg, B. (1998). Rationality and power: Democracy in practice. University of Chicago Press.

Flyvbjerg, B. (2001). Making social science matter: Why social inquiry fails and how it can succeed again. Cambridge University Press.

Flyvbjerg, B., Bruzelius, N., \& Rothengatter, W. (2003). Megaprojects and risk: An anatomy of ambition. Cambridge University Press.

Folke, C. (2006). Resilience: The emergence of a perspective for social-ecological systems analyses. Global Environmental Change, 16(3), 253-267.

Fournier, V., \& Grey, C. (2000). At the critical moment: Conditions and prospects for critical management studies. Human Relations, 53(1), 7-32.

Frederiksen, M. (2016). Material dys-appearance: Decaying futures and contested temporal passage. In P. Bjerregaard, A. E. Rasmussen, \& T. F. Sørensen (Eds.), Materialities of passing: Transformation, transition and transcience (pp. 49-64). Routledge.

Garud, R., \& Karnøe, P. (2001a). Path dependence and creation. Psychology Press.

Garud, R., \& Karnøe, P. (2001b). Path creation as a process of mindful deviation. In R. Garud \& P. Karnøe (Eds.), Path dependence and creation (pp. 1-38). Lawrence Erlbaum Associates Publishers.

Garud, R., Kumaraswamy, A., \& Karnøe, P. (2010). Path dependence or path creation? Journal of management Studies, 47(4), 760-774.

Gledhill, J. (2009). Power in political anthropology. Journal of Power, 2(1), 9-34.

Golsorkhi, D., Rouleau, L., Seidl, D., \& Vaara, E. (Eds.). (2010). Cambridge handbook of strategy as practice. Cambridge University Press.

Grabher, G. (2004). Temporary architectures of learning: Knowledge governance in project ecologies. Organization Studies, 25(9), 1491-1514.

Gunder, M., \& Hillier, J. (2009). Planning in ten words or less: A Lacanian entanglement with spatial planning. Ashgate Publishing.

Harrison, R., Blickem, C., Lamb, J., Kirk, S., \& Vassilev, I. (2019). Asset-based community development: Narratives, practice, and conditions of possibility-
A qualitative study with community practitioners. SAGE Open, 9(1). https://doi.org/10.1177/2158244 018823081

Hautz, J., Seidl, D., \& Whittington, R. (2017). Open strategy: Dimensions, dilemmas, dynamics. Long Range Planning, 50(3), 298-309.

Helmke, G., \& Levitsky, S. (2004). Informal Institutions and comparative politics: A research agenda. Perspectives on Politics, 2(4), 725-740.

Hillier, J. (2002). Shadows of power: An allegory of prudence in land-use planning. Routledge.

Hoch, C. (2016). Utopia, scenario and plan: A pragmatic integration. Planning Theory, 15(1), 6-22.

Hood, C., \& Peters, G. (2004). The middle aging of new public management: Into the age of paradox? Journal of Public Administration Research and Theory, 14(3), 267-282.

Hüther, O., \& Krücken, G. (2013). Hierarchy and power: A conceptual analysis with particular reference to new public management reforms in German universities. European Journal of Higher Education, 3(4), 307-323.

Hyysalo, S., Marttila, T., Perikangas, S., \& Auvinen, K. (2019). Codesign for transitions governance: A mid-range pathway creation toolset for accelerating sociotechnical change. Design Studies, 63, 181-203.

Innes, J. E. (1989). Disappointments and legacies of social indicators. Journal of Public Policy, 429-432.

Jacobsson, B., Pierre, J., \& Sundström, G. (2015). Governing the embedded state: The organizational dimension of governance. Oxford University Press.

Jay, A. (1967). Management and Machiavelli. London.

Kemp, R., Loorbach, D., \& Rotmans, J. (2007). Transition management as a model for managing processes of co-evolution towards sustainable development. The International Journal of Sustainable Development and World Ecology, 14(1), 78-91.

Kjaer, P., \& Vetterlein, A. (2018). Regulatory governance: Rules, resistance and responsibility. Contemporary Politics, 24(5), 497-506.

Lindberg, K., Czarniawska, B., \& Solli, R. (2015). After NPM? Scandinavian Journal of Public Administration, 19(2), 3-6.

Louis, M. R., \& Bartunek, J. M. (1992). Insider/outsider research teams: Collaboration across diverse perspectives. Journal of Management Inquiry, 1(2), 101-110.

Lovio, R., Mickwitz, P., \& Heiskanen, E. (2011). Path dependence, path creation and creative destruction in the evolution of energy systems. In R. Wustenhagen \& R. Wuebker (Eds.), The handbook of research on energy entrepreneurship (pp. 274-304). Edward Elgar.

Luhmann, N. (1989). Ecological communication. University of Chicago Press.

Luhmann, N. (1990). Political theory in the welfare state. de Gruyter.

Luhmann, N. (1995). Social systems. Stanford University Press. 
Luhmann, N. (1997). Limits of steering. Theory, Culture and society, 14(1), 41-57.

Luhmann, N. (2018). Organization and decision. Cambridge University Press.

MacKenzie, D., Muniesa, F., \& Siu, L. (Eds.). (2007). Do economists make markets? On the performativity of economics. Princeton University Press.

McFarlane, C. (2012). Rethinking informality: Politics, crisis, and the city. Planning Theory \& Practice, 13(1), 89-108.

McLain, R. J., \& Lee, R. G. (1996). Adaptive management: Promises and pitfalls. Environmental management, 20(4), 437-448.

Mintzberg, H., \& Lampel, J. (1999). Reflecting on the strategy process. MIT Sloan Management Review, 40(3), 21-30.

Mintzberg, H., \& Waters, J. A. (1985). Of strategies, deliberate and emergent. Strategic Management Journal, 6(3), 257-272.

Newig, J., Voß, J. P., \& Monstadt, J. (Eds.). (2013). Governance for sustainable development: Coping with ambivalence, uncertainty and distributed power. Routledge.

Orpen, C. (1996). Dependency as a moderator of the effects of networking behavior on managerial career success. The Journal of Psychology, 130(3), 245-248.

Paschen, J. A., \& Ison, R. (2014). Narrative research in climate change adaptation-Exploring a complementary paradigm for research and governance. Research Policy, 43(6), 1083-1092.

Paterson, J., \& Teubner, G. (1998). Changing maps: Empirical legal autopoiesis. Social \& Legal Studies, 7(4), 451-486.

Pierson, P. (2000). Increasing returns, path dependence, and the study of politics. American Political Science Review, 94(02), 251-267.

Pressman, J. L., \& Wildavsky, A. (1984). Implementation: How great expectations in Washington are dashed in Oakland; or, why it's amazing that federal programs work at all, this being a saga of the economic development administration as told by two sympathetic observers who seek to build morals on a foundation (Vol. 708). University of California Press.

Rap, E. (2006). The success of a policy model: Irrigation management transfer in Mexico. The Journal of Development Studies, 42(8), 1301-1324.

Rip, A. (2006). A co-evolutionary approach to reflexive governance-And its ironies. In J. P. Voß, D. Bauknecht, \& R. Kemp (Eds.), Reflexive governance for sustainable development (pp. 82-101). Edward Elgar.

Rotmans, J., \& Loorbach, D. (2009). Complexity and transition management. Journal of Industrial Ecology, 13(2), 184-196.

Schienstock, G. (2004). From path dependency to path creation: A new challenge to the systems of innovation approach. In G. Schienstock (Ed.), Embracing the knowledge economy. The dynamic transformation of the Finnish innovation system (pp. 3-27). Edward Elgar.

Schirmer, W., \& Hadamek, C. (2007). Steering as paradox: The ambiguous role of the political system in modern society. Cybernetics and Human Knowing, 14(2/3), 133-150.

Scott, J. C. (1998). Seeing like a state: How certain schemes to improve the human condition have failed. Yale University Press.

Seidl, D. (2007). General strategy concepts and the ecology of strategy discourses: A systemic-discursive perspective. Organization Studies, 28(2), 197-218.

Seidl, D. (2016). Organisational identity and self-transformation: An autopoietic perspective. Routledge.

Seidl, D., \& Becker, K. H. (Eds.). (2005). Niklas Luhmann and organization studies. Malmö: Liber.

Stack, M., \& Gartland, M. P. (2003). Path creation, path dependency, and alternative theories of the firm. Journal of Economic Issues, 37(2), 487-494.

Tadajewski, M., Maclaran, P., \& Parsons, E. (Eds.). (2011). Key concepts in critical management studies. Sage.

Teubner, G. (1998). Legal irritants: Good faith in British law or how unifying law ends up in new divergencies. The Modern Law Review, 61(1), 11-32.

Teubner, G., \& Willke, H. (1984). Kontext und Autonomie: gesellschaftliche Selbststeuerung durch reflexives Recht [Context and autonomy: Social self-control through reflexive law]. Zeitschrift für Rechtssoziologie, 5(1), 4-35.

Throgmorton, J. A. (2003). Planning as persuasive storytelling in a global-scale web of relationships. Planning Theory, 2(2), 125-151.

Turnhout, E., Hisschemöller, M., \& Eijsackers, H. (2007). Ecological indicators: Between the two fires of science and policy. Ecological Indicators, 7(2), 215-228.

Valentinov, V. (2014). The complexity-sustainability trade-off in Niklas Luhmann's social systems theory. Systems Research and Behavioral Science, 31(1), 14-22.

Valentinov, V. (2017). Materiality in natural resource management: A systems theory view. Journal of Environmental Policy and Planning, 19(3), 323-326.

Van Assche, K., Beunen, R., \& Duineveld, M. (2013). Evolutionary governance theory: An introduction. Springer Science and Business Media.

Van Assche, K., Beunen, R., \& Duineveld, M. (2014). For$\mathrm{mal} /$ informal dialectics and the self-transformation of spatial planning systems: An exploration. Administration \& Society, 46(6), 654-683.

Van Assche, K., Beunen, R., Duineveld, M., \& Gruezmacher, M. (2017). Power/knowledge and natural resource management: Foucaultian foundations in the analysis of adaptive governance. Journal of Environmental Policy and Planning, 19(3), 308-322.

Van Assche, K., Beunen, R., Gruezmacher, M., \& Duineveld, M. (2020a). Rethinking strategy in environmental governance. Journal of Environmental Policy and Planning, 22(5), 695-708. 
Van Assche, K., Duineveld, M., \& Beunen, R. (2014). Power and contingency in planning. Environment and Planning A, 46(10), 2385-2400.

Van Assche, K., Gruezmacher, M., \& Deacon, L. (2020b). Land use tools for tempering boom and bust: Strategy and capacity building in governance. Land Use Policy, 93, Article 103994.

Van Assche, K., \& Verschraegen, G. (2008). The limits of planning: Niklas Luhmann's systems theory and the analysis of planning and planning ambitions. Planning theory, 7(3), 263-283.

Van Assche, K., Verschraegen, G., \& Gruezmacher, M. (2021). Strategy for collectives and common goods: Coordinating strategy, long-term perspectives and policy domains in governance. Futures, 128, Article 102716.

Van Assche, K., Verschraegen, G., Valentinov, V., \& Gruezmacher, M. (2019). The social, the ecological, and the adaptive. Von Bertalanffy's general systems theory and the adaptive governance of social-ecological systems. Systems Research and Behavioral Science, 36(3), 308-321.

Van Dijk, T. (2006). How the hands of time mould planning instruments: Iterative adaptation pushing limits in rural areas. European Planning Studies, 14(10), 1449-1471.

Van Dijk, T. (2011). Imagining future places: How designs co-constitute what is, and thus influence what will be.
Planning Theory, 10(2), 124-143.

Van Tatenhove, J. (2011). Integrated marine governance: Questions of legitimacy. Mast, 10(1), 87-113.

Verschraegen, G. (2015). The evolution of welfare state governance. In R. Beunen, K. Van Assche. \& M. Duineveld (Eds.), Evolutionary governance theory (pp. 57-71). Springer.

Von Bertalanffy, L. (2015). General systems theory; foundations, development, applications (13rd ed.). George Braziller.

Voß, J. P., \& Freeman, R. (2016). Introduction: Knowing governance. In J. P. Voß \& R. Freeman (Eds.), Knowing governance (pp. 1-33). Palgrave Macmillan.

Wagner, J. A., III, Stimpert, J. L., \& Fubara, E. I. (1998). Board composition and organizational performance: Two studies of insider/outsider effects. Journal of Management Studies, 35(5), 655-677.

Whittington, R. (1996). Strategy as practice. Long Range Planning, 29(5), 731-735.

Willke, H. (2007). Smart governance: Governing the global knowledge society. Campus Verlag.

Willke, H. (2014). Systemtheorie III: Steuerungstheorie [System theory III: A theory of control]. UTB GmbH.

Young, O. R. (1991). Political leadership and regime formation: On the development of institutions in international society. International Organization. 45, 281-308.

Žižek, S. (1989). The sublime object of ideology. Verso.

\section{About the Authors}

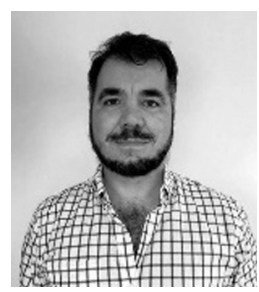

Kristof Van Assche is Full Professor in planning, governance and development at the University of Alberta since 2016. He is also affiliated at Bonn University as Senior Fellow in the Center for Development Research (ZEF) and with Memorial University (Newfoundland) as Research Fellow in the Harris Centre for Regional Policy. Before coming to Alberta in 2014 he worked at Bonn University as Senior Researcher, in Minnesota State University (St. Cloud) as Associate Professor and at Wageningen University as Assistant Professor. He is interested in evolution and innovation in governance, with focus areas in spatial planning and design, development and environmental policy. He has worked in various countries, often combining fieldwork with theoretical reflection: systems theories, interpretive policy analysis, institutional economics, post-structuralism and others. Together with some colleagues he has developed Evolutionary Governance Theory (EGT), which aims to discern realistic modes of transition and reform, between social engineering and laissez faire.

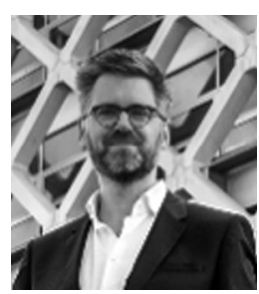

Martijn Duineveld is Associate Professor at the Cultural Geography Group at Wageningen University. His research programme is named "Urban Governance and the Politics of Planning and Design." He is co-founder and active contributor to the emerging body of literature on Evolutionary Governance Theory and has been involved in many international research and consultancy projects situated in Argentina, Uganda, Georgia and Russia. He also studies urban fringes and cities in the Netherlands, such as The Bulb region (2005-2010), Groningen (2010-2012) and Arnhem (2013-2018). In these cases, he explores the power interplays between local politicians, planners, designers, project developers and citizens.

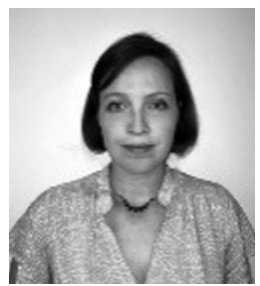

Monica Gruezmacher has a PhD from the Center for Development Studies at the University of Bonn. She has been particularly interested in human-nature interactions, studying ways in which social changes bring about changes in the use and management of natural resources. For the past years she has been exploring the challenges of planning for long-term sustainability in rural communities of Western Canada and Newfoundland, but has had also substantial experience in the Amazon region (particularly in Colombia where she is originally from). 


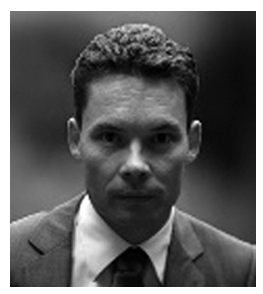

Raoul Beunen is Associate Professor of Environmental Governance at the Open University, the Netherlands. His research explores the potentials and limitations of environmental policy and planning in the perspective of adaptive governance and sustainability. It focuses on innovation and evolution in governance, paying attention to the dynamics of policy implementation and integration, multi-level governance, stakeholder involvement, and the performance of institutional structures. 